\title{
Diuretic and serum electrolyte regulation potential of aqueous methanolic extract of Solanum surattense fruit validates its folkloric use in dysuria
}

Muhammad Masood Ahmed', Shumaila Andleeb ${ }^{1}$, Fatima Saqib ${ }^{1}$, Musaddique Hussain ${ }^{2}$, Most. Nurtaj Khatun ${ }^{3}$, Bashir Ahmad $\mathrm{Ch}^{1}$ and Hafizur Rahman ${ }^{4^{*}}$

\begin{abstract}
Background: Solanum surattense Burm. (Solanaceae) is traditionally used for management of various ailments. The study was conducted for provision of pharmacological justification for folkloric uses of Solanum surattense in the treatment of dysuria.

Methods: Rats were randomly divided into 5 groups, each of $(n=6)$. Aqueous methanolic fruit extract of $S$. surattense were also administered intraperitoneally to the rats at doses of 50,70 and $100 \mathrm{mg} / \mathrm{kg}$. Furosemide $(10 \mathrm{mg} / \mathrm{kg}$ i.p) was used as standard drug whereas controls were given saline solution ( $40 \mathrm{~mL} / \mathrm{kg}$ i.p). The electrolytes in urine were measured using a flame photometer whereas serum sodium, potassium, calcium, bicarbonate and blood urea nitrogen (BUN) were determined by using an automatic analyzer. Urine osmolality was assayed by the micro-osmometer.

Results: The extract $S$. surattense induced diuretic effects in a dose-dependent manner as compared with control. Upon administration of extract (70 and $100 \mathrm{mg} / \mathrm{kg}$ ), we observed the prominent $(p<0.01)$ increase in the urine volume and osmolality in comparison to control group. However, plant extract $(100 \mathrm{mg} / \mathrm{kg})$ significantly increase the urinary electrolyte excretion especially calcium $(p<0.05)$ to that of the furosemide whereas level of magnesium remains constant. Moreover, our results showed a decrease in serum levels of sodium, potassium, calcium and blood urea nitrogen (BUN), but concentration dependent increase in bicarbonate was found in the test groups. There was no substantial change in the $\mathrm{pH}$ of urine samples of the extract-treated groups.
\end{abstract}

Conclusion: These results indicate that $S$. surattense investigated exert its action by causing diuresis in the treatment of dysuria.

Keywords: Solanum surattense, Diuretic activity, Renal canculi, Dysuria

\section{Background}

Plants produce a wide range of biologically active molecules which are enriched source of various medicines. In Pakistan and Bangladesh, people use many indigenous herbs and plants as curative drug without any scientific rationale of their beneficial effects. Previously, many studies have been conducted to investigate the pharmacological and phytochemical characteristics of herbs and other plants to provide a scientific approach to their

\footnotetext{
* Correspondence: hafiz_bot@yahoo.com

${ }^{4}$ Department of Botany, University of Rajshahi, Rajshahi 6205, Bangladesh

Full list of author information is available at the end of the article
}

traditional uses $[1,2]$. In certain cases, conventional healers use medicinal plant extracts as diuretics. Dearing et al. reported that almost 85 plant species have shown diuretic potential [3]. It has been demonstrated that different crude drugs of plant origin have shown promise to treat various urologic diseases [4]. Dysuria is the condition in which pain is felt during urination due to urinary tract infections [5] and common among people accompanying the findings of renal calculi [6]. Symptomatic treatment of dysuria is primarily based on the use of diuretics, anti inflammatory and antibacterial drugs. In addition, Commission E has granted approval 
for some plant extracts being used as diuretics [4]. However both in vivo and in vitro studies, the use of traditional therapies as diuretics in different urinary disorders remains to be elusive.

Selection of systematic method for the pharmacological evaluation of botanical products based on their use in the traditional systems of medicine. Solanum surattense Burm. Syn. S. Xanthocarpum (Solanaceae) locally called as Kantikari (yellow berried night shade) is a commonly growing perennial herb and used for curing urologic ailments in both Ayurvedic and Traditional Chinese Medicine system [7-11]. The S. surattense fruits are edible and used as diuretic, anti-inflammatory and antiasthmatic [11-13]. The use of root decoction of $S$. surattense as effective diuretic is common among local communities [14, 15]. Later, Siddiqui et al. have found some potential phyto-constituents in S. surattense fruits showing the diuretic activities [7]. Moreover, Patel et al. has demonstrated the anti-urolithiatic effects of S. surattense fruit extract on rat model of nephrolithiasis as well as having potential to excrete magnesium, calcium oxalate and uric acid [11]. The Ayurveda doctors are extensively using the extract of $S$. surattense fruits and whole plant in their prescriptions to treat dysuria might be due to its diuretic efficiency [7, 9]. The decoction of the entire plant is utilized by local traditional healers to treat gonorrhea in their common practice $[9,10]$. The extract of $S$. surattense has shown a strong antibacterial activity against Pseudomonas aeruginosa in vitro experimental settings $[5,16]$. In previous reports, S. surattense treatment showed antioxidant effects by improving the renal function in rat model of urinary lithiasis $[11,15]$. Recently, Pandey and his colleagues revealed the scientific reasons for metal phytoextraction potential of Solanum surattense plants found in localities near Jharkhand, India [17]. The seeds of $S$. surattense are used to treat cough and asthma due to its expectorant action [12] whereas paste of leaves is utilized for reliving pains [13]. S. surattense is also used as cardio tonic probably due to alkaloidal glycosides presence [7, 9]. Furthermore, scientific investigations revealed the $S$. surattense fruit shows hypoglycemic effects in normal and diabetic rats $[18,19]$, wound healing activity [20], physicochemical function [21], cytotoxic activity like various Egyptian plants [22, 23], anthelmintic and antimalarial properties [24]. Phytochemical studies of S. surattense berries contain $\beta$-sitosterol with phenolic methyl caffeate, caffeic acid and coumarins like aesculetin and aesculin [7]. Other constituents like solasonine, solamargine, solasurine [25], torvoside $\mathrm{K}$ and $\mathrm{L}$, khasianine [26], aculeatiside A and solamargine [27] are also found in S. surattense fruit.

Previous studies showed that indigenous plants having ethnomedical reputation of diuresis to treat dysuria and hypertension were investigated for their diuretic activity in rats and humans [28-30]. Moreover, the serum electrolytes and blood urea nitrogen alterations have been found upon 'Aloe vera' extract treatment in rats [31]. However, having enough understanding about numerous pharmacological activities of $S$. surattense being used in urinary-lithiasis animal model, but still there is a need to justify the implication of Kantakari fruit to induce diuresis and reduce serum electrolytes level.

Although S. surattense has traditionally been used to treat dysuria and other urinary ailments, but no pharmacological record is available in order to validate such conventional uses. The current study was done to examine the diuretic potential and probable mode of action which may authenticate the traditional use of the $S$. surattense fruit in dysuria.

\section{Methods \\ Drugs and chemicals}

Furesemide, from Sanofi-aventis Pakistan Limited, Karachi, diuretic drug used for reference. Sodium chloride was obtained from BDH Laboratory supplies, Poole, England whereas methanol (70 \%) was purchased from Merck (Germany). All other reagents utilized in experiments, were purchased from Sigma Chemicals Co. St Louis, USA. All chemicals were of high purity and grade.

\section{Plant collection and extraction}

The plant of S. surattense was collected from Kot Addu, Pakistan, in September 2012 and was identified by taxonomist, Prof. Dr. Altaf Ahmad Dasti of the Institute of Pure and Applied Biology, Bahauddin Zakariya University, Multan (voucher number STW 644). The fruit (berries) of S. surattense were separated from plant were washed and dried under shade for 4 weeks. The material was mechanically powdered and passed through a 20 $\mathrm{mm}$ sieve after keeping them in an electric oven at $35{ }^{\circ} \mathrm{C}$ for $24 \mathrm{~h}$. About $990 \mathrm{~g}$ of the grounded plant material was subjected to extraction by triple maceration process with methanol (70 \%) in air tight glass jars at room temperature for 10 to 12 days with occasional shaking. The organic waste was separated by percolation with muslin cloth. The obtained liquid was further strained by passing through whatman.no 1 filter paper. This process was repeated for three times to obtain dark brown thick jelly like consistency; named Ss.ME. The moisture was removed by making it in lyophilized form with the help of rotary evaporator (Rotavapor) under reduced pressure at $38{ }^{\circ} \mathrm{C}$ to obtain approximate yield of $19.1 \%$. The extract was kept in light protected air-tight bottle at $-4{ }^{\circ} \mathrm{C}[2]$.

\section{Acute toxicity test}

Acute toxicity test was performed by using 2, 4, 6, 8 and $10 \mathrm{~g} / \mathrm{kg}$ of Ss.ME, as previously described [32]. 


\section{Preliminary phytochemical screening}

Phytochemical evaluation was performed to determine different constituents in extract of $S$. surattense using the methods which are previously described [33, 34]. Mayer's test was performed and formation of white precipitate (ppt) showed the presence of alkaloids in $S$. surattense extract. Frothing test was accomplished to identify the saponins in extract. Specified tests for tannins and phenols were done. The ppt of green or blue color appeared upon addition of ferric chloride to the extract mixture. Further tests were performed for sterols and tri-terpenoids. The brown ring was appeared at the junction of two layers following addition of few drops of acetic anhydride in initially boiled and then cooled solution of plant extract. The upper layer changed its color to green and red showed the presence of sterols and tri-terpenoids in S. surattense extract. [33, 34].

\section{Animals and housing conditions}

Adult albino rats $(\hat{\delta} / q)$ with average weight $220-240 \mathrm{~g}$ were given tap water and diet mixture containing choker, dry milk and chicken feed (locally made) in the ratio of 2:1:2. The rats were placed in polycarbonate cages of size $(50 \times 35 \times 20 \mathrm{~cm})$. The animals were housed under standard temperature $\left(25-28{ }^{\circ} \mathrm{C}\right)$ and humidity conditions. The experiments were performed with the approval of ethical committee of Bahauddin Zakariya University, Multan, Pakistan.

\section{Dose preparation S. surattense extract}

The methanolic extract of $S$. surattense was mixed in saline $(0.9 \%)$ in a sterilized tube. Then vortex the mixture and kept in Ultrasonic cleaner (Elma, Model LC20H, Germany). Three doses of various concentrations (50, 70 and $100 \mathrm{mg} / \mathrm{kg}$ ) were made by ultrafiltration and $\mathrm{pH}$ determination (Ino Lab, Model pH7310, Germany).

\section{Measurement of diuretic activity}

The method used with minor modification from Gilani et al. [29] was used to determine the diuretic activity. All doses of extract were administered intraperitoneally. Rats were fasted overnight but given access to water. Animals were separated into 5 groups with $n=6$ in each. The group A (control) was given saline $(40 \mathrm{~mL} / \mathrm{kg}$ ), group B, C and D (test group) were given different doses of S. surattense extract $(50,70$ and $100 \mathrm{mg} / \mathrm{kg}$ ) while group E was treated with furosemide $(10 \mathrm{mg} / \mathrm{kg})$ used as reference. After treatment, the animals were transferred in individually ventilated separate cages (Techniplast, Italy). The graduated vials were used for urine collection whereas volume was measured at 1, 2, 4 and $6 \mathrm{~h}$ and monitored hourly. The mean urine volume was calculated and expressed as $\mathrm{mL} / 100 \mathrm{~g} /$ body weight $[29,35]$.

\section{Urinary electrolyte and osmolality analysis}

Sodium, potassium, calcium, magnesium excretion level and $\mathrm{pH}$ were measured in urine sample of rat at the end of the mentioned experimental time. The concentration of sodium and potassium was expressed in mol whereas $\mu \mathrm{mol}$ and mmol/100 g body weight for calcium and magnesium. Electrolyte levels were determined by using a standardized flame photometer (Corning, Model 410 Classic, UK) [29, 35]. The $\mathrm{pH}$ of urine samples was noted with $\mathrm{pH}$ meter [36]. Urine osmolality was analyzed by micro-osmometer (Model 3350, Advanced Instruments, Inc.) with minor alternation in method [29].

\section{Blood sample collection}

The blood samples from the animals were initially obtained through the retro-orbital plexus, after which they were killed by cervical dislocation and more blood was collected via heart puncture. The blood sample collected from each rat was put in lithium-heparinized sample bottles. Serum was centrifuged at $3000 \mathrm{rpm}$ at $4{ }^{\circ} \mathrm{C}$ for 10-15 min [31].

\section{Determination of serum electrolytes, bicarbonate and blood urea nitrogen (BUN)}

Serum sodium, potassium, calcium, bicarbonate and blood urea nitrogen were measured by an automatic analyzer (MSLAB08, MSL, China).

\section{Statistical analysis}

The results are expressed as mean \pm S.E.M (Standard error mean). The significance between the test groups and the control group were analyzed using unpaired $t$ tests. Data were analyzed using Graph Pad Prism. The results were taken significant statistically when $p<0.05$.

\section{Results}

Phytochemical evaluation of S. surattense

Aqueous methanolic extract of $S$. surattense was analyzed to check different pharmacologically active phytoconstituents

Table 1 Effect of S. surattense fruit extract on urine volume

\begin{tabular}{lllll}
\hline Treatment & \multicolumn{4}{l}{ Urine volume $(\mathrm{ml} / 100 \mathrm{~g}$ of body weight) } \\
\cline { 2 - 5 } & $1 \mathrm{~h}$ & $2 \mathrm{~h}$ & $4 \mathrm{~h}$ & $6 \mathrm{~h}$ \\
\hline Saline $40 \mathrm{~mL} / \mathrm{kg}$ & $0.74 \pm 0.32$ & $0.96 \pm 0.17$ & $0.64 \pm 0.13$ & $1.16 \pm 0.15$ \\
S. surattense & $0.85 \pm 0.15$ & $1.12 \pm 0.13$ & $1.30 \pm 0.17$ & $2.08 \pm 0.12^{*}$ \\
$50 \mathrm{mg} / \mathrm{kg}$ & & & & \\
S. surattense & $1.08 \pm 0.14$ & $1.23 \pm 0.18$ & $1.62 \pm 0.15^{*}$ & $2.34 \pm 0.16^{*}$ \\
$70 \mathrm{mg} / \mathrm{kg}$ & & & & \\
S. surattense & $1.26 \pm 0.11$ & $1.52 \pm 0.14^{*}$ & $1.86 \pm 0.13^{*}$ & $2.72 \pm 0.09^{* *}$ \\
$100 \mathrm{mg} / \mathrm{kg}$ & & & & \\
Furosemide & $1.94 \pm 0.17$ & $2.34 \pm 0.15^{*}$ & $2.93 \pm 0.10^{*}$ & $3.54 \pm 0.13^{* *}$ \\
$10 \mathrm{mg} / \mathrm{kg}$ & & & & \\
\hline
\end{tabular}

Each value is expressed as a mean \pm S.E.M $(n=6){ }^{*} p<0.05$ and ${ }^{* *} p<0.01$ 
Table 2 Effect of S. surattense fruit extract on Osmolarity

\begin{tabular}{lllll}
\hline Treatment & \multicolumn{4}{l}{ Urine osmolality (mOsm) } \\
\cline { 2 - 5 } & $1 \mathrm{~h}$ & $2 \mathrm{~h}$ & $4 \mathrm{~h}$ & $6 \mathrm{~h}$ \\
\hline Saline $40 \mathrm{~mL} / \mathrm{kg}$ & $162 \pm 28$ & $194 \pm 36$ & $203 \pm 33$ & $282 \pm 68$ \\
S. surattense $50 \mathrm{mg} / \mathrm{kg}$ & $175 \pm 45$ & $245+28$ & $285 \pm 35^{*}$ & $328 \pm 57^{*}$ \\
S. surattense $70 \mathrm{mg} / \mathrm{kg}$ & $210 \pm 32$ & $306 \pm 35^{*}$ & $294 \pm 26$ & $452 \pm 25^{* *}$ \\
S. surattense $100 \mathrm{mg} / \mathrm{kg}$ & $260 \pm 55$ & $421 \pm 42^{*}$ & $365 \pm 38^{*}$ & $372 \pm 30$ \\
Furosemide $10 \mathrm{mg} / \mathrm{kg}$ & $320 \pm 70$ & $380 \pm 85^{*}$ & $645 \pm 36^{* *}$ & $390 \pm 58$ \\
\hline
\end{tabular}

Each value is expressed as a mean \pm S.E.M $(n=6){ }^{*} p<0.05$ and ${ }^{* *} p<0.01$

and we found that the extract contains alkaloids, tannins, saponin, sterols and tri-terpenoids whereas anthraquinones were absent.

\section{Acute toxicity test}

Acute toxicity of S. surattense fruit extract was checked at various doses $(2,4,6,8$ and $10 \mathrm{~g} / \mathrm{kg})$. We found no change in animal behavior and mortality up to the maximum dose i-e $10 \mathrm{~g} / \mathrm{kg}$. These observations indicated that the extract was safe up to the highest test dose.

\section{Urine volume and $\mathrm{pH}$}

The methanolic extract of S. surattense $(100 \mathrm{mg} / \mathrm{kg})$ and standard furosemide showed significant diuretic activity versus control at the $6^{\text {th }} \mathrm{h}(p<0.01 ; 2.72 \pm 0.09 \mathrm{~mL})$ and $(p<0.01 ; 3.54 \pm 0.13 \mathrm{~mL})$, respectively. The lowest test dose $(50 \mathrm{mg} / \mathrm{kg})$ of Ss.ME also showed marked diuretic activity $(p<0.05 ; 2.08 \pm 0.12 \mathrm{~mL})$ versus control at the 6 th $\mathrm{h}$. The urine output was also significant $(p<0.05)$ during the $2^{\text {nd }}, 4^{\text {th }}$ and $6^{\text {th }} \mathrm{h}$ after treatment with the dose $(70 \mathrm{mg} / \mathrm{kg}$ ) of Ss.ME (Table 1). The $\mathrm{pH}$ of urine samples after administration of Ss.ME 50, 70 and $100 \mathrm{mg} / \mathrm{kg}$ doses was $6.5,6.8$ and 6.7 , respectively. We found no significant change in mean urinary $\mathrm{pH}$.

\section{Osmolality of urine}

As shown in Table 2, the osmolality of urine of the control group remained constant, irrespective of time; however the animals administered with Ss.ME showed significant rise in osmolality of urine than that of the controls. With an exception of doses 70 and $100 \mathrm{mg} / \mathrm{kg}$ induce a significant urinary osmolality $(p<0.05)$ during the second hour. However, the test dose of Ss.ME $(70 \mathrm{mg} / \mathrm{kg})$ showed highest osmolality $(p<0.01 ; 452 \pm$ $25 \mathrm{mOsm})$ at $6^{\text {th }} \mathrm{h}$. Moreover, the furosemide-treated group showed a significant rise in the osmolality of urine time dependently, with a maximum increase during the $4^{\text {th }} \mathrm{h}(p<0.01 ; 645 \pm 36 \mathrm{mOsm})$.

\section{Electrolytes excretion level in urine}

The urinary sodium and potassium level was measured at $1,2,4$ and $6 \mathrm{~h}$ whereas calcium and magnesium concentration was analyzed after $6^{\text {th }} \mathrm{h}$ from the urine samples, as shown in Tables 3 and 4. Overall, the urine content of these electrolytes of the control animals was same. Among the three doses of extract tested, significantly higher $(p<0.01)$ concentration of the urinary $\mathrm{Na}^{+}$ $(291 \pm 23 \mathrm{~mol})$ and $\mathrm{K}^{+}(79 \pm 7.5 \mathrm{~mol})$ excretion was observed in the animals treated with dose $100 \mathrm{mg} / \mathrm{kg}$ of Ss.ME at the $6^{\text {th }} h$. However, the significant $(p<0.05)$ amount of $\mathrm{Na}^{+}$and $\mathrm{K}^{+}$excreted in the urine after treatment with Ss.ME during the $2^{\text {nd }}$ and $4^{\text {th }}$ h. Furosemide caused significant increase in $\mathrm{Na}^{+}$and $\mathrm{K}^{+}$excretion in urine during every hour control group whereas a marked increment $(p<0.01)$ in the urinary $\mathrm{Na}^{+}(305 \pm 27 ; 324 \pm$ $15 \mathrm{~mol})$ and $\mathrm{K}^{+}(89 \pm 13$; $91 \pm 20 \mathrm{~mol})$ levels were noted after furosemide treatment at the $4^{\text {th }}$ and $6^{\text {th }} \mathrm{h}$, respectively (Table 3).

At the $6^{\text {th }} \mathrm{h}$, urinary calcium $\left(\mathrm{Ca}^{2+}\right)$ excretion was found to be significantly higher in the Ss.ME and furosemide treated groups. However, the highest calcium excretion level in urine after treatment with Ss.ME dose $100 \mathrm{mg} / \mathrm{kg}(p<0.01 ; 29.16 \pm 2.95 \mu \mathrm{mol})$ and furosemide treated group $(p<0.01 ; 36.20 \pm 5.75 \mu \mathrm{mol})$ was noted than that in the control group. Moreover, no significant difference was observed among control, test and furosemide treated groups regarding the $6^{\text {th }} \mathrm{h}$ urinary excretion of magnesium $\left(\mathrm{Mg}^{2+}\right)$ content (Table 4).

\section{Serum level of sodium, potassium, calcium, bicarbonate and blood urea nitrogen (BUN)}

Among three test groups, we observed concentration dependent decrease in the serum levels of sodium $(p<0.01)$ and potassium $(p<0.05)$ in the test group after treatment with Ss.ME dose $100 \mathrm{mg} / \mathrm{kg}$ and

Table 3 Total excretion of sodium and potassium in urine over a period of $6 \mathrm{~h}$ after treatment with S. surattense fruit extract

\begin{tabular}{|c|c|c|c|c|c|c|c|c|}
\hline \multirow[t]{2}{*}{ Treatment } & \multicolumn{4}{|l|}{$\mathrm{Na}^{+}(\mathrm{mol})$} & \multicolumn{4}{|l|}{$\mathrm{K}^{+}(\mathrm{mol})$} \\
\hline & $1 \mathrm{~h}$ & $2 \mathrm{~h}$ & $4 \mathrm{~h}$ & $6 \mathrm{~h}$ & $1 \mathrm{~h}$ & $2 \mathrm{~h}$ & $4 \mathrm{~h}$ & $6 \mathrm{~h}$ \\
\hline Saline $40 \mathrm{~mL} / \mathrm{kg}$ & $62 \pm 38$ & $114 \pm 25$ & $106 \pm 10$ & $98 \pm 29$ & $21 \pm 5$ & $35 \pm 7$ & $28 \pm 10$ & $33 \pm 11$ \\
\hline S. surattense $50 \mathrm{mg} / \mathrm{kg}$ & $88 \pm 13$ & $107 \pm 17$ & $127 \pm 25$ & $132 \pm 16^{*}$ & $24 \pm 7$ & $38 \pm 6$ & $59 \pm 11^{*}$ & $65 \pm 10^{*}$ \\
\hline S. surattense $70 \mathrm{mg} / \mathrm{kg}$ & $111 \pm 9$ & $128 \pm 16$ & $181 \pm 19^{*}$ & $257 \pm 20^{*}$ & $33 \pm 6.5$ & $47 \pm 13$ & $63 \pm 16^{*}$ & $69 \pm 14^{*}$ \\
\hline S. surattense $100 \mathrm{mg} / \mathrm{kg}$ & $120 \pm 21$ & $184 \pm 14^{*}$ & $192 \pm 32^{*}$ & $291 \pm 23^{* *}$ & $42 \pm 8$ & $58 \pm 15^{*}$ & $68 \pm 8.5^{*}$ & $79 \pm 7.5^{* *}$ \\
\hline Furosemide 10 mg/kg & $144 \pm 35$ & $247 \pm 26^{*}$ & $305 \pm 27^{* *}$ & $324 \pm 15^{* *}$ & $66 \pm 5.9^{*}$ & $78 \pm 9^{*}$ & $89 \pm 13^{* *}$ & $91 \pm 20^{* *}$ \\
\hline
\end{tabular}

Each value is expressed as a mean \pm S.E.M $(n=6){ }^{*} p<0.05$ and ${ }^{* *} p<0.01$ 
Table 4 Effect of S. surattense fruit extract on urinary calcium and magnesium

\begin{tabular}{lcc}
\hline Treatment & $\mathrm{Ca}^{2+} \mu \mathrm{mol} / 6 \mathrm{~h}$ & $\mathrm{Mg}^{2+} \mathrm{mmol} / 6 \mathrm{~h}$ \\
\hline Saline $40 \mathrm{~mL} / \mathrm{kg}$ & $6.68 \pm 4.52$ & $0.08 \pm 0.02$ \\
S. surattense $50 \mathrm{mg} / \mathrm{kg}$ & $12.32 \pm 5.14^{*}$ & $0.07 \pm 0.01$ \\
S. surattense $70 \mathrm{mg} / \mathrm{kg}$ & $18.17 \pm 3.91^{*}$ & $0.07 \pm 0.01$ \\
S. surattense $100 \mathrm{mg} / \mathrm{kg}$ & $29.16 \pm 2.95^{* *}$ & $0.08 \pm 0.02$ \\
Furosemide $10 \mathrm{mg} / \mathrm{kg}$ & $36.20 \pm 5.75^{* *}$ & $0.09 \pm 0.01$ \\
\hline
\end{tabular}

Each value is expressed as a mean \pm S.E.M $(n=6)^{*} p<0.05$ and ${ }^{* *} p<0.01$

furosemide treated group $(p<0.01)$ as compared to the controls (Fig. 1a and b). We found significant increase in serum bicarbonate $(p<0.05)$ in $100 \mathrm{mg} / \mathrm{kg}$ Ss.ME and furosemide treated animals in comparison to control group (Fig. 2). However, there was marked decline in the serum calcium and blood urea nitrogen level $(p<0.01)$ in the rats after administration of Ss.ME dose $100 \mathrm{mg} / \mathrm{kg}$ and furosemide comparable to test dose $70 \mathrm{mg} / \mathrm{kg}(p<0.05)$ than that of control group (Fig. 3a and b).

\section{Discussion}

The present study was under taken to validate the folkloric use of S. surattense fruit in dysuria by evaluating its diuretic activity.

The results of our study validated that $S$. surattense aqueous methanolic extract exhibited a significant but dose dependent rise in the urine output in rats, like standard diuretic drug, furosemide [36]. Similarly, with increase in the urine volume, Ss.ME also boosted the excretion of $\mathrm{Na}^{+} \mathrm{K}^{+}$and $\mathrm{Ca}^{2+}$ in urine, as triggered by furosemide when compared with controls. Loop diuretics not only increase the urinary outflow, are also known to increase the electrolyte excretion in urine, called as saluretic [36] whereas the presence of diuretic constituents are likely to supplement the use of $S$. surattense in dysuria [7, 11]. The active constituent responsible for diuretic activity of the extract has not yet been found, but the phytochemical assay revealed that S. surattense contains alkaloids, phenols, saponins and sterols [7, 37]. The chemical structures and pharmacological properties of tannins and saponins are so intricate. However, the diuretic activity of the plant extract might be due to initiation of multiple mechanisms. Previous studies demonstrated that tannins in plants have shown both diuretic and vasodilator potential [31]. Previously, it has been reported that root extract of Ananas comosus enhanced diuresis and osmolality which was not dependent on salt content in plant [28]. Consistent to the previous findings, the different doses of Ss.ME increases the osmolality of urine together with excretion of electrolytes per unit time may help to investigate the mechanisms by which S. surattense shows diuretic action [11].

Furthermore, we investigated the various concentrations of Ss.ME on renal function by analyzing the serum

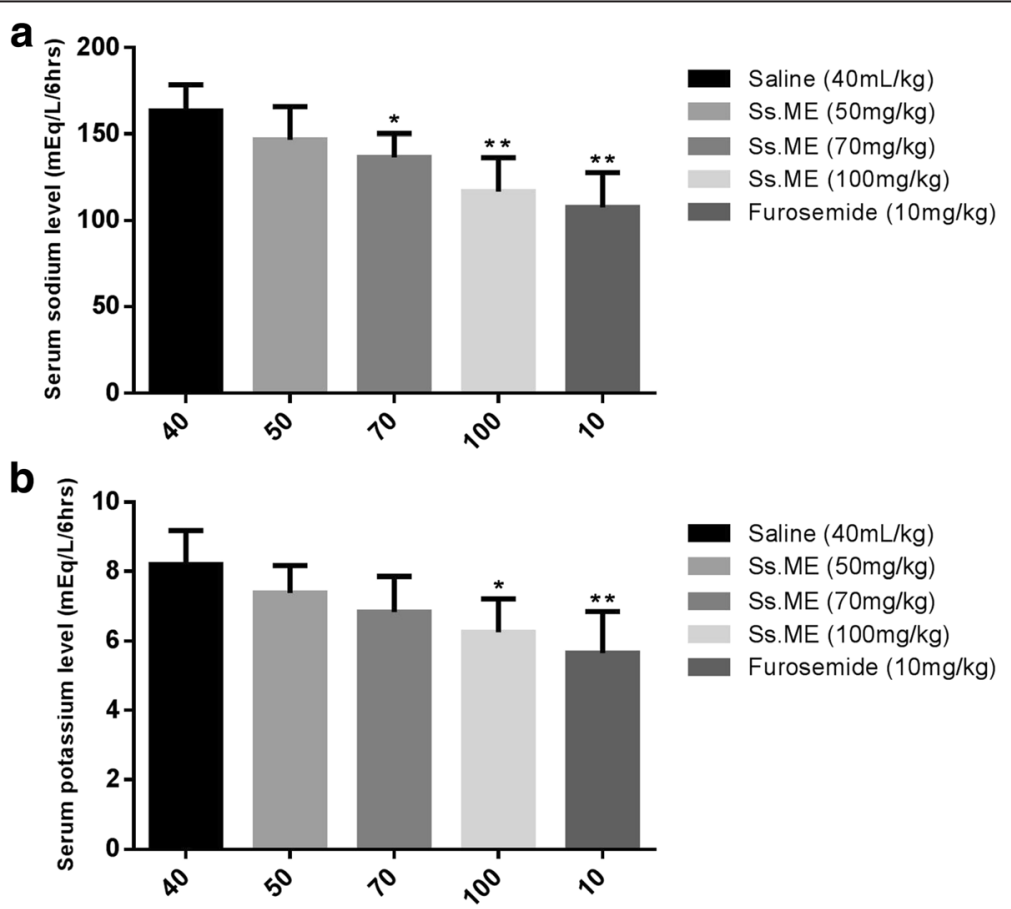

Fig. 1 Effect of Solanum surattense fruit extract (SS.ME) and furosemide on serum levels of $\mathbf{a} \mathrm{Na}^{+}$and $\mathbf{b} \mathrm{K}^{+}$in rats. Values are shown as mean \pm S.E.M., $n=6 .{ }^{*} p<0.05$ and ${ }^{* *} p<0.01$ versus control 


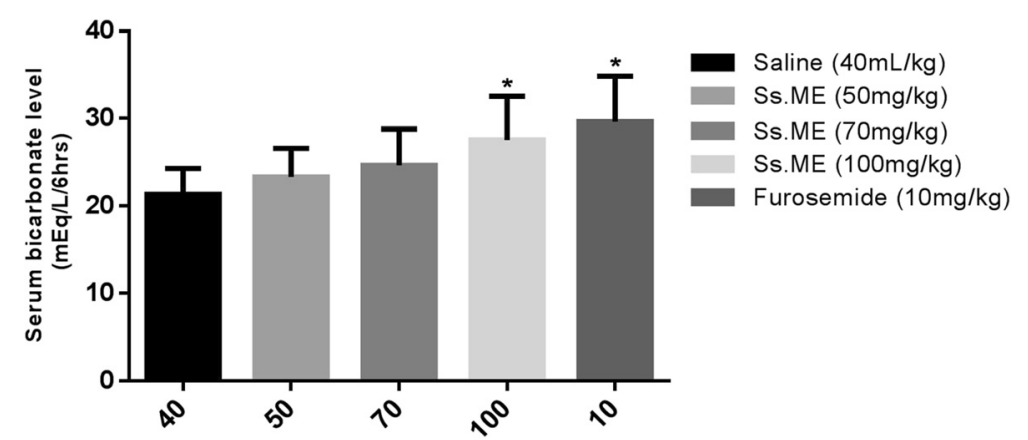

Fig. 2 Effect of Solanum surattense fruit extract (Ss.ME) and furosemide on serum levels of bicarbonate in rats. Values are shown as mean \pm S.E.M., $n=6 .{ }^{*} p<0.05$ and ${ }^{* *} p<0.01$ versus control

level of electrolytes and blood urea nitrogen. However, recent studies showed that $S$. surattense fruit extract acted as anti-urolithiatic in rats [11]. The result from this study demonstrated that Ss.ME treatment induced a change in electrolyte levels in experimental animals as explained in previous report [31]. Moreover, it has been proved that electrolytes play an important role in muscle contraction and relaxation [38]. Saka and colleagues has shown the reduction in sodium and potassium ions is correlated with the increased bicarbonate level after plant extract treatment [31]. Here, we also found Ss.ME dose dependent significant reductions in the serum level of sodium, potassium and calcium whereas serum bicarbonate concentration is increased. whereas These results show that Ss.ME induce alterations in electrolytes level evident by low plasma level of sodium, and rise in bicarbonate level though significant, was not sufficient to cause metabolic alkalosis [31]. Previous studies showed that high protein and fat diets play a key role in the pathogenesis of calcium-containing renal stones and increases blood urea nitrogen $[5,11]$. The plasma concentrations of urea and calcium could be used as indicator of renal function. However, we found the substantial decreases in blood urea nitrogen $(\mathrm{BUN})$ and calcium
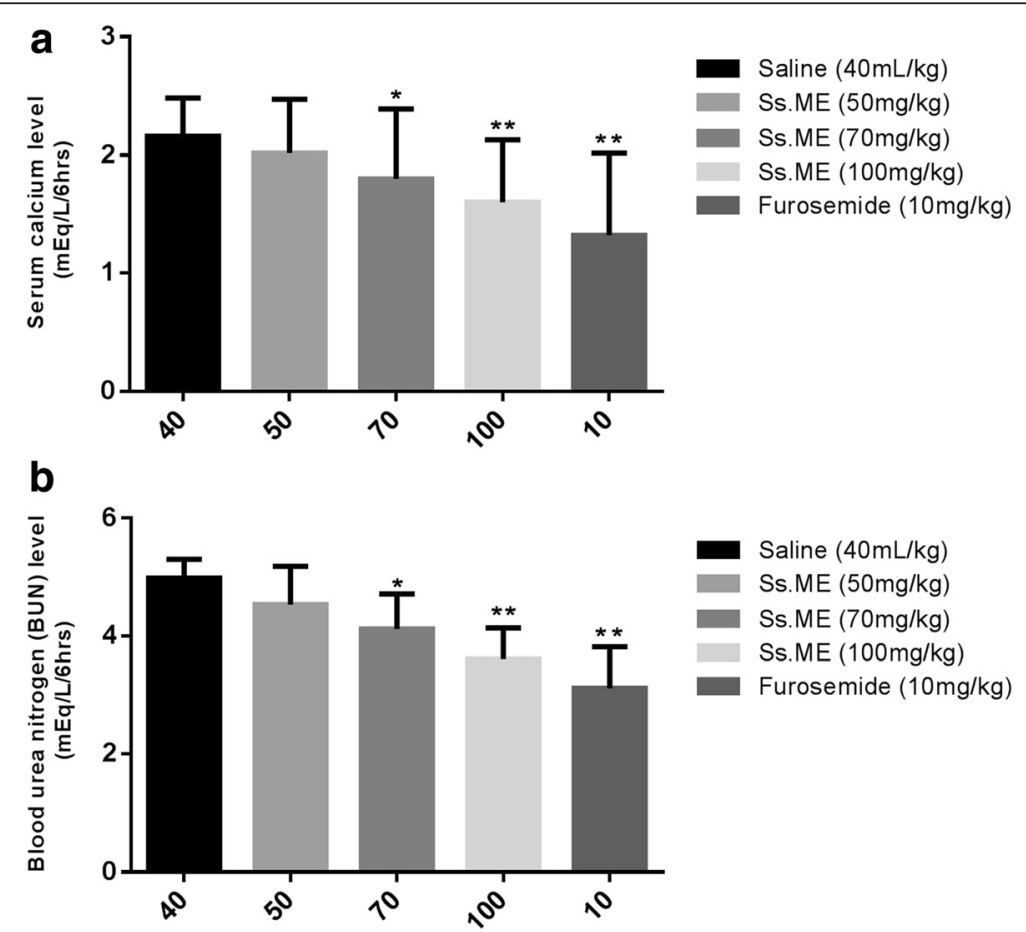

Fig. 3 Effect of Solanum surattense fruit extract (SS.ME) and furosemide on $\mathbf{a}$ serum $\mathrm{Ca}^{+2}$ and $\mathbf{b}$ blood urea nitrogen (BUN) in rats. Values are shown as mean \pm S.E.M., $n=6 .{ }^{*} p<0.05$ and ${ }^{* *} p<0.01$ versus control 
after S. surattense fruit extract treatment whereas similar parameters have been found in rats with urinary-lithiasis [11]. The decline in serum calcium and urea concentrations depicts that Ss.ME dose dependently enhances the renal function.

It has been documented that saponins showed diuretic effect in connection with steroids and vitamin D while tannins have shown the diuretic and vasodilator effects [39]. Therefore, we can suggest that the diuretic potential of the methanolic extract of $S$. surattense is due to the presence of phenolic caffeic acid and methyl caffeate as secondary metabolites [7, 11]. However, antibacterial effect of $S$. surattense plant extract against Pseudomonas aeruginosa $[5,16]$ most probably linked with diuretic action of the Ss.ME to treat dysuria [11]. Hence, further studies are required to elucidate the efficacy and efficiency of Solanum surattense berries.

\section{Conclusion}

By the findings of our study, we can conclude that $S$. surattense exhibits substantial diuresis when compared to that of furosemide whereas decline in serum calcium and blood urea nitrogen levels provide strong mechanistic background for its diuretic potential in dysuria treatment.

\begin{abstract}
Abbreviations
BUN, blood urea nitrogen; $\mathrm{Ca}^{2+}$, calcium; $\mathrm{K}^{+}$, potassium; i.p, intraperitoneally $\mathrm{Mg}^{2+}$, magnesium; $\mathrm{ml}$, milliliter; $\mathrm{mOsm}$, milliosmole; $\mathrm{mmol}$, millimole; $\mathrm{Na}^{+}$, sodium; ppt, precipitate Ss.ME, methanolic extract of Solanum surattense; S.E.M, standard error mean; $\mu \mathrm{mol}$, micromole
\end{abstract}

\section{Acknowledgements}

We are thankful to laboratory staff of Faculty of Pharmacy, Bahauddin Zakariya University Multan, Pakistan for their help in smooth running of experiments.

\section{Funding}

Not applicable.

\section{Availability of data and materials}

Data are all contained within the paper.

\section{Authors' contributions}

MMA, SA and FS designed and carried out the experimental work. BA, HR, MH and MNK analyzed the statistical data and interpretation of results. $\mathrm{HR}$ and $\mathrm{MH}$ drafted and critically evaluated the manuscript. All authors read and approved the final manuscript.

\section{Competing interests}

The authors declare that they have no competing interests.

\section{Consent for publication}

Not applicable.

\section{Ethics approval and consent to participate}

All the surgical and experimental procedures were performed with the approval of ethical committee of Bahauddin Zakariya University, Multan, Pakistan (2012-13), which reviewed the procedures based on NIH Guidelines.

\section{Author details}

${ }^{1}$ Faculty of Pharmacy, Bahauddin Zakariya University, Multan, Pakistan. ${ }^{2}$ Department of Pharmacology, School of Medicine, Zhejiang University, Hangzhou, China. ${ }^{3}$ Department of Zoology, Rajshahi College, National
University, Gazipur, Bangladesh. ${ }^{4}$ Department of Botany, University of Rajshahi, Rajshahi 6205, Bangladesh.

Received: 14 December 2015 Accepted: 27 May 2016

Published online: 03 June 2016

\section{References}

1. Saqib F, Ahmed MG, Janbaz KH, Dewanjee S, Jaafar HZ, Zia-Ul-Haq M. Validation of ethnopharmacological uses of Murrayapaniculata in disorders of diarrhea, asthma and hypertension. BMC Complement Altern Med. 2015;15:319.

2. Janbaz KH, Arif J, Saqib F, Imran I, Ashraf M, Zia-UI-Haq M, et al. In-vitro and in-vivo validation of ethnopharmacological uses of methanol extract of Isodon rugosus Wall. ex Benth. (Lamiaceae). BMC Complement Altern Med. 2014;14:71-83.

3. Dearing MD, Mangione AM, Karasov WH. Plant secondary compounds as diuretics: An overlooked consequence. Am Zool. 2001:41:890-901.

4. Yarnell E. Botanical medicines for the urinary tract. World J Urol. 2002;20:285-93.

5. Mittal R, Aggarwal S, Sharma S, Chhibber S, Harjai K. Urinary tract infections by Pseudomonas aeruginosa: a minireview. J Infect Public Health. 2009;2:101-11.

6. Taylor EN, Curhan GC. Role of nutrition in the formation of calciumcontaining kidney stones. Nephron Physiol. 2004;98:p55-63.

7. Siddiqui S, Faizi S, Siddiqui B. Studies in the chemical constituents of the fresh berries of Solanum xanthocarpum. J Chem Soc Pak. 1983;5:14-21.

8. Khare CP. Indian Medicinal Plants, An Illustrated Dictionary. Berlin/Heidelberg, New Delhi: Springer; 2007. p. 615.

9. Parmar S, Gangwal A, Sheth N. Solanum xanthocarpum (yellow berried night shade): a review. Der Pharm Lett. 2010;2:373-83.

10. Ghani A. Medicinal Plants of Bangladesh: Chemical Constituents and Uses. 1st ed. Dhaka: The Asiatic Society of Bangladesh; 1998. p. 135. 175-79.

11. Patel P, Patel M, Saralai M, Gandhi T. Antiurolithiatic effects of Solanum Xanthocarpum fruit extract on Ethylene-Glycol induced Nephrolithiasis in Rats. J Young Pharm. 2012:4:164-70.

12. Vadnere GP, Gaud RS, Singhai AK. Evaluation of Anti-asthamatic property of Solanum Xanthocarpum flower extract. Pharmacologyonline. 2008;1:513-22.

13. Emmanuel $S$, Ignacimuthu $S$, Perumalsamy $R$, Amalraj T. Antiinflammatory activity of Solanum trilobatum. Fitoterapia. 2006;77:611-2.

14. Kiritikar KR, Basu BD. Indian Medicinal Plants. 2nd ed. Dehredun: Mahendra Pal Sing Publication; 1987.

15. Priyadarsini R, Tamilarasi K, Karunambigai A, Gayathri DS. Antioxidant potential of the leaves and roots of Solanum surattense. Plant Arch. 2010;10:815-8.

16. Ghani MS, Faroog MU, Khan MTJ. Phytochemical investigations and evaluation of antibacterial and irritant potential of different extracts of whole plant of Solanum xanthocarpum Schrad and Wendl. J Chin Chem Soc. 2010;57:1257-62.

17. Panday SK, Bhattacharya T, Chakraborty S. Metal phytoremediation potential of naturally growing plants on fly ash dumpsite of Patatu thermal power station, Jharkhand, India. Int J Phytoremediation. 2016;18:87-93.

18. Gupta S, Mal M, Bhattacharya P. Evaluation of hyperglycemia potential of Solanum xanthocarpum fruit in normal and streptozotocin induced diabetic rats. Eur Bull Drug Res. 2005;13:55.

19. Kar DM, Maharana L, Pattnaik S, Dash GK. Studies on hypoglycaemic activity of Solanum xanthocarpum fruit extract in rats. J Ethnopharmacol. 2006;108:251-6.

20. Kumar N, Prakash D, Kumar P. Wound healing activity of Solanum xanthocarpum Schrad. \& Wendl. fruits. Indian J Nat Prod Resour. 2010;1:470-5.

21. Meena AK, Rao MM, Kandale A, Sharma K, Singh U, Yadav A. Evaluation of physicochemical and standardization parameters of Solanum xanthocarpum Schrad. \& Wendl. Int J Chem Anal Sci. 2010;1:47-9.

22. Arthan D, Svasti J, Kittakoop P, Pittayakhachonwutb D, Tanticharoenb M, Thebtaranonth Y. Antiviral isoflavonoid sulfate and steroidal glycosides from the fruits of Solanum torvum leaves. Phytochemistry. 2002;59:459-63.

23. El-Seedi HR, Burman R, Mansour A, Turki Z, Boulos L, Gullbo J, Göransson U. The traditional medical uses and cytotoxic activities of sixty-one Egyptian plants: Discovery of an active cardiac glycoside from Urginea maritime. J Ethnopharmacol. 2013;145:746-57.

24. Mohan L, Sharma P, Srivastava CN. Comparative efficacy of Solanum xanthocarpum extracts alone and in combination with a synthetic pyrethroid, cypermethrin, against malaria vector, Anopheles stephensi. Southeast Asian J Trop Med Public Health. 2007:38:256-60.

25. Gawande A, Wankhade S, Shankhapal KV, Shinde GB. Isolation, purification and characterization of solasodine-A steroidal alkaloid from Solanum surattense berries. Indian Drugs. 1990;28:149-50. 
26. lida Y, Yanai Y, Ono M, Ikeda T, Nohara T. Three unusual 22-b-O-23hydroxy-(5a)-spirostanol glycosides from the fruits of Solanum torvum. Chem Pharm Bull. 2005;53:1122-5.

27. Weissenberg M. Isolation of solasodine and other steroidal alkaloids and sapogenins by direct hydrolysis - extraction of Solanum plants or glycosides. Phytochemistry. 2001;58:501-8.

28. Sripanidkulchai B, Wongpanich V, Laupattarakasem P, Suwansaksri J, Jirakulsomchok D. Diuretic effects of selected Thai indigenous medicinal plants in rats. J Ethnopharmacol. 2001;75:185-90.

29. Gilani AH, Jabeen Q, Khan A, Shah AJ. Gut modulatory, blood pressure lowering diuretic and sedative activities of cardamom. J Ethnopharmacol. 2008:3:463-72.

30. Clare BA, Conoroy RS, Spelman K. The diuretic effect in human subjects of an extract of Taraxacum officinale folium over a single day. J Altern Complement Med. 2009;15:929-34.

31. Saka W, Akhigbe R, Popoola O, Oyekunle O. Changes in Serum Electrolytes, Urea, and Creatinine in Aloe Vera-treated Rats. J Young Pharm. 2012;4:78-81.

32. Hussain M, Raza SM, Janbaz KH. Pharmacological evaluation and validation for the folkloric use of Oligochaeta ramose (Roxb.) in constipation and diarrhea. Bangladesh J Pharmacol. 2014;9:617-23.

33. Evans WC. Trease and Evans' Pharmacognosy, $16^{\text {th }}$ ed. Elsevier Health Sciences; 2009. Saunders Ltd. ISBN: 978-0-7020-2933-2. http://www.us. elsevierhealth.com/trease-and-evans-pharmacognosy-9780702029332. html. http://www.amazon.com/Trease-Evans-Pharmacognosy-16e/dp/ 0702029335\#reader_0702029335.

34. Sofowara EA. Medical plants and traditional medicine in Africa. Ibadan: Spectrum Books Ltd; 2006. p. 1-163.

35. Ratnasooriya W, Pieris K, Samaratunga U, Jayakody J. Diuretic activity of Spilanthesacmella flowers in rats. J Ethnopharmacol. 2004;2:317-20.

36. Jackson EK. Diuretics. In: Hardman JG, Limbird LE, Gilman AG, editors. Goodman and Gilman's The Pharmacological Basis of Therapeutics. 10th ed. New York: McGraw-Hill; 2001. p. 757-88.

37. Shahiladevi S, Jayanthi G, Jegadeesan M. Preliminary phytochemical studies on Solanum surattense burm. F Seeds Anc Sci Life. 2006;26:59-64.

38. Brouns F, Saris W, Schneider H. Rationale for upper limits of electrolyte replacement during exercise. Int J Sport Nutr. 1992;2:229-38.

39. Martin-Herrera D, Abdala S, Benjumea D, Gutierrez-Luis J. Diuretic activity of some Withania aristata Ait. fractions. J Ethnopharmacol. 2008:3:496-9.

\section{Submit your next manuscript to BioMed Central and we will help you at every step:}

- We accept pre-submission inquiries

- Our selector tool helps you to find the most relevant journal

- We provide round the clock customer support

- Convenient online submission

- Thorough peer review

- Inclusion in PubMed and all major indexing services

- Maximum visibility for your research

Submit your manuscript at www.biomedcentral.com/submit

) Biomed Central 